\title{
EFFECT OF TIME-TEMPERATURE BINOMIAL IN OBTAINING BIOCHEMICAL OXYGEN DEMAND OF DIFFERENT WASTEWATERS
}

\author{
MATEUS P. DE MATOS ${ }^{1}$, ALISSON C. BORGES ${ }^{2}$, ANTONIO T. DE MATOS ${ }^{3}$, \\ EDSON F. DA SILVA ${ }^{4}$, MAURO A. MARTINEZ ${ }^{5}$
}

\begin{abstract}
Studies on the effects of temperature and time of incubation of wastewater samples for the estimation of biodegradable organic matter through the biochemical oxygen demand (BOD), that nowadays are rare, considering that the results of the classic study of STREETER \& PHELPS (1925) have been accepted as standard. However, there are still questions how could be possible to reduce the incubation time; whether the coefficient of temperature $(\theta)$ varies with the temperature and with the type of wastewater and if it approaches 1.047. Aiming the elucidation of these questions, wastewater samples of dairy, swine and sewage treated in septic tanks were incubated at temperatures of 20,30 and $35^{\circ} \mathrm{C}$, respectively for $5,3.16$ and 2.5 days. From the parameter of deoxygenation coefficient at $20{ }^{\circ} \mathrm{C}\left(\mathrm{k}_{20}\right), \theta_{30}$ and $\theta_{35}$ were calculated. The results indicated that $\theta$ values changes with the type of wastewater, however does not vary in the temperature range between 30 and $35{ }^{\circ} \mathrm{C}$, and that the use of 1.047 value did not implied significant differences in obtaining $\mathrm{k}$ in a determined $\mathrm{T}$ temperature. Thus, it is observed that the value of $\theta$ can be used to estimate the required incubation time of the samples at different temperatures.
\end{abstract}

KEYWORDS: degradation, deoxygenation coefficient, temperature coefficient, Streeter \& Phelps.

\section{EFEITO DO BINÔMIO TEMPO-TEMPERATURA NA OBTENÇÃO DA DEMANDA BIOQUÍMICA DE OXIGÊNIO EM DIFERENTES ÁGUAS RESIDUÁRIAS}

RESUMO: Pesquisas sobre o efeito da temperatura e do tempo de incubação de amostras de águas residuárias, para estimativa da matéria orgânica biodegradável, por meio da demanda bioquímica de oxigênio (DBO), atualmente são raras, tendo em vista que têm sido aceitos, como padrão, os resultados obtidos no trabalho clássico de STREETER \& PHELPS (1925). Entretanto, ainda permanecem questionamentos, como se seria possível reduzir o tempo de incubação; se o valor do coeficiente de temperatura $(\theta)$ varia com a temperatura e com o tipo de água residuária e se aproxima de 1,047. Com o objetivo de elucidar tais questões, foram incubadas amostras de águas residuárias de laticínios, suinocultura e esgotos sanitários tratados em fossa séptica, sob as temperaturas de 20; 30 e $35{ }^{\circ} \mathrm{C}$, respectivamente, por 5; 3,16 e 2,5 dias. A partir do parâmetro coeficiente de desoxigenação a $20{ }^{\circ} \mathrm{C}\left(\mathrm{k}_{20}\right)$, foram calculados $\theta_{30}$ e $\theta_{35}$. Os resultados indicaram que o valor de $\theta$ muda com o tipo de água residuária, embora não varie na faixa de temperatura entre 30 e $35{ }^{\circ} \mathrm{C}$, e que o emprego do valor de 1,047 não implicou diferenças significativas na obtenção de $\mathrm{k}$ para uma determinada temperatura T. Assim, observa-se que esse valor de $\theta$ pode ser empregado caso se queira estimar o tempo necessário de incubação das amostras em diferentes temperaturas.

PALAVRAS-CHAVE: coeficiente de desoxigenação, coeficiente de temperatura, degradação, Streeter \& Phelps.

\footnotetext{
${ }^{1}$ Eng $^{\underline{0}}$ Agrícola e Ambiental, Doutorando em Saneamento, Depto. de Eng. Sanitária e Ambiental, UFMG/Belo Horizonte - MG, matmatos_eaa@yahoo.com.br.

${ }^{2}$ Eng $^{\underline{0}}$ Civil, Prof. Adjunto, Departamento de Engenharia Agrícola, UFV/Viçosa-MG, borges@ufv.br.

${ }^{3}$ Eng $^{\underline{0}}$ Agrícola, Prof. Associado, Departamento de Engenharia Agrícola, UFV/Viçosa - MG, atmatos@ufv.br.

${ }^{4}$ Eng ${ }^{0}$ Agrícola e Ambiental, Doutorando em Eng. Agrícola, Depto. de Eng. Agrícola, UFV/Viçosa - MG, edsfaria@yahoo.com.br.

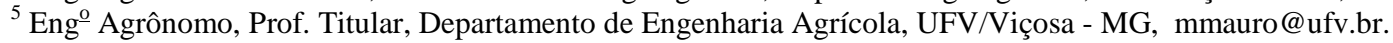

Recebido pelo Conselho Editorial em: 26-9-2012

Aprovado pelo Conselho Editorial em: 12-11-2013
} 


\section{INTRODUCTION}

The biochemical oxygen demand (BOD) is the amount of oxygen used by non-photosynthetic microorganisms to oxidize organic compounds, being therefore the indirect quantification of the concentration of organic matter present in wastewater and water bodies. Small concentrations of dissolved oxygen (DO) indicate extensive contamination of water, with the possibility of mortality of fish and other aerobic aquatic animals (MENEZES et al., 2009). Thus, the BOD is an important variable and of reference for environmental legislation and studies of self-purification in rivers, besides criteria for dimensioning of biological treatment systems for wastewater.

For the quantification of BOD, the analysis was made after the sample incubation for 5 days at $20{ }^{\circ} \mathrm{C}$, obtaining $\mathrm{BOD}_{5}^{20}$. The long time required for the analysis is precisely one of the main limitations to its use in studies or in monitoring that requires quick responses, so that it is possible to act with environmental impacts or operation of biological treatment systems.

The rise in temperature favors higher multiplication and faster metabolism of microorganisms as well as increased availability of organic material by increasing the hydrolysis of the organic compounds (METCALF \& EDDY, 2003). Thus, the increase in temperature, since within the optimum range for the development of mesophilic microorganisms, which is of $30-35{ }^{\circ} \mathrm{C}$, may, according to MAY (1971) and JI et al. (2010), provide an increase in the rate of oxygen depletion, allowing more rapid degradation of the organic material. The increase in BOD progression of exercise provided by the temperature rise can be verified by the increase in deoxygenation coefficient (k), which is dependent on the concentration of biodegradable organic matter and temperature, and indicates the consumption of DO over time besides the speed that reaches the last biochemical oxygen demand $\left(\mathrm{BOD}_{\mathrm{u}}\right)$. The $\mathrm{BOD}_{\mathrm{u}}$, maximum potential of oxygen demand of wastewater (GREEN \& WARD, 2011) is related to the BOD obtained at t time, in days, by the coefficient k [eq.(1)]:

$$
\mathrm{BOD}_{\mathrm{t}}=\mathrm{BOD}_{\mathrm{u}}\left(1-\mathrm{e}^{-\mathrm{kt}}\right)
$$

CARPENTER et al. (1968) found an increase in deoxygenation coefficient with the increase of incubation temperature of the sample (wastewater from paper and cellulose processing), and obtained the maximum degradation rate at $30{ }^{\circ} \mathrm{C}$. Considering that, with the increase of incubation temperature $\mathrm{T}$, there is an increase in the value of $\mathrm{k}$, it is possible then to reduce the incubation time to achieve a value similar to the one that would be obtained if the incubation occurred at $20{ }^{\circ} \mathrm{C}$ (HOWINGTON, 1994). The relation between temperature and deoxygenation coefficient was demonstrated by the Arrhenius relation modified by STREETER \& PHELPS (1925), shown in [eq.(2)]:

$$
\mathrm{k}_{\mathrm{T}}=\mathrm{k}_{20} \theta^{(\mathrm{T}-20)}
$$

STREETER \& PHELPS (1925) found for samples of sewage and surface waters, in the range between 10 and $37.5{ }^{\circ} \mathrm{C}$, a value of temperature coefficient $(\theta)$ of 1.047. THERIAULT (1927), under similar conditions, found the same value. The study encouraged other studies in which it was found that the value of $\theta$ could not be generalized for all conditions and types of wastewater. CARPENTER et al. (1968) found a value of 1.016 for effluents of paper and cellulose processing. GOTAAS (1948) and ZANONI (1967), using sewage, verified that $\theta$ varied within certain temperature ranges. Nevertheless, the studies became scarcer and the values proposed by STREETER \& PHELPS (1925) were adopted as standard, considering that the large standard deviation, natural in the analysis of BOD, did not justify such precision in the value of $\theta$. Furthermore, although a few exceptions (FIA et al., 2007; UDEIGWE \& WANG, 2010), the studies are still scarce on modeling and obtaining parameters of degradation of organic material of wastewater other than the sanitary sewer. Thus, the aim of this study was to verify whether if it is possible to reduce the incubation time of the samples to obtain similar results to the $\mathrm{BOD}_{5}^{20}$, if the 
temperature coefficient varies with the type of wastewater and temperature, and if its value is close to 1.047 .

\section{MATERIAL AND METHODS}

The study was conducted at the Laboratory of Water Quality, of the Department of Agricultural Engineering, in the Federal University of Viçosa, located in Viçosa - state of Minas Gerais (MG), in Brazil, in April and May of 2011, with the following wastewater used in the study:

- effluent from the septic tank of the sewage treatment system from the Bosque Acamari Condominium (ESF), located in Viçosa-MG, collected in the Experimental Area of Waste Treatment, of the Department of Agricultural Engineering, Federal University of Viçosa;

- raw dairy wastewater (ARL), collected in a facility located in Barrinha neighborhood, also in Viçosa-MG.

- raw swine effluent (ARS), collected in Água Limpa Farm, located in the Rural Area of Viçosa-MG.

The time elapsed between collection and incubation of samples was not higher than 6 hours, aiming to prevent the occurrence of problems reported in ZANONI (1965), APHA (2012) and SIMON et al. (2011), such as loss of viability of the sample (consumption of organic material).

The samples were subjected to different times and temperatures $\left(20,30\right.$ and $\left.35{ }^{\circ} \mathrm{C}\right)$ of incubation. Incubation times were obtained using Equation 2, with temperature coefficient equal to 1.047. Under these conditions, to a temperature of $30{ }^{\circ} \mathrm{C}$, the deoxygenation coefficient is about 1.58 times higher than at $20{ }^{\circ} \mathrm{C}$, and thus, the time could be reduced to 3.16 days. Similarly, $\mathrm{k}_{35}$ is twice as large, and 2.50 days would be sufficient to obtain similar value to the BOD, after incubation of the sample for 5 days at $20^{\circ} \mathrm{C}$. The experiment was arranged, in Completely Randomized Design (CRD), with 5 replicates used for each sample at each temperature of incubation. The BOD was obtained by considering the difference in oxygen concentration after the sample was incubated in the pre-established time-temperature binomial, and the quantification of dissolved oxygen was obtained using the method of Winkler (iodometric), according to APHA (2012). The measurements were made on day 0, after 2.5, 3.16 and 5 days of incubation of the samples of each analyzed wastewater. At each day of incubation, the reading of the BOD samples were made in quintuplicate and also of "white", consisting of nutrient solutions without the presence of aliquots of the wastewaters. In Winkler flasks that received aliquots of the analyzed effluents, 10, 0.025 and $0.1 \mathrm{~mL}$ of ESF, ARL and ARS were added respectively. To calculate the BOD, the equation presented in APHA (2012) and modified by MATOS (2012a) was used:

$$
\mathrm{BOD}_{\mathrm{t}}=\left\{\frac{\left[\left(\mathrm{DO}_{\mathrm{Wh} 0}-\mathrm{DO}_{\mathrm{t}}\right)-\left(\mathrm{DO}_{\mathrm{Wh} 0}-\mathrm{DO}_{\mathrm{Wht}}\right)\right]\left(\frac{\mathrm{V}_{\mathrm{f}}-\mathrm{V}_{\mathrm{sam}}}{\mathrm{V}_{\mathrm{fWht}}}\right)}{\frac{\mathrm{V}_{\mathrm{sam}}}{\mathrm{V}_{\mathrm{f}}}}\right\}
$$

where,

$\mathrm{BOD}_{\mathrm{t}}$ - biochemical oxygen demand performed on any day "t" (mg L $\left.\mathrm{L}^{-1}\right)$;

$\mathrm{DO}_{\mathrm{Wh} 0}$ - dissolved oxygen in the "white" sample obtained after incubation for 0 day $\left(\mathrm{mg} \mathrm{L}^{-1}\right)$;

$\mathrm{DO}_{\mathrm{t}}$ - dissolved oxygen obtained after incubation of the sample for "t" days (mg L $\mathrm{L}^{-1}$ );

$\mathrm{DO}_{\text {Wht }}$ - dissolved oxygen in the "white" sample after incubation for "t" days (mg L ${ }^{-1}$ );

$\mathrm{V}_{\mathrm{f}}$ - volume of the flask total of BOD (mL);

$\mathrm{V}_{\text {sam }}$ - volume of wastewater sample added to the flask of BOD (mL), and

$\mathrm{V}_{\mathrm{fWht}}$ - volume of the flask of BOD of the "white" incubated for "t" days (mL). 
This formula excludes possible depletions occurring in the dilution water, which could occur in the event of contamination with agents that provide oxygen consumption of the ambient.

The samples were incubated on the established days, making readings of $\mathrm{BOD}_{2.5}^{35}, \mathrm{BOD}_{3.16}^{30}$ and $\mathrm{BOD}_{5}^{20}$ of the ESF, ARL and ARS samples. Considering that the BOD is a large standard deviation variable, since reading errors occur, the normality of reagents may be different from the specified; it may occur greater or minor presence of microorganisms or the metabolic activity of these may be further accelerated in some of the replications than in others, there are the obtainment of not consistent (or discrepant) data (MATOS, 2012b). As a criterion for selection of those results that could compose a reliable database, we evaluated the relation between biochemical (BOD) and chemical (COD) demands. The BOD values that provided unusual ratios were discarded; data from at least 3 of the 5 repetitions were used. The mean values, after discarding the discrepant results were then compared for each wastewater by the "t" test $(\alpha=0.05)$, verifying if it is possible to estimate the amount of change with the time-temperature binomial.

The estimated temperature coefficient of the wastewater on the two evaluated temperatures was obtained by means of [eq.(4)]:

$$
\left.\theta=\left[\frac{\ln \left[1-\left(\mathrm{BOD}_{\mathrm{t} 1}^{\mathrm{T}} / \mathrm{BOD}_{\mathrm{t}}^{20}\right)\left(1-\mathrm{e}^{-\mathrm{k}_{20} \mathrm{t}}\right)\right]}{-\mathrm{k}_{20} \mathrm{t}_{1}}\right]\right]^{\left(\frac{1}{\mathrm{~T}-20}\right)}
$$

where,

$\mathrm{BOD}_{t 1}^{T}$ - BOD performed in time "t $\mathrm{t}_{1}$ " of sample incubation, on temperature "T" (mg L $\left.{ }^{-1}\right)$; $\mathrm{BOD}_{t}^{20}$ - BOD performed in time "t" of sample incubation, on temperature $20^{\circ} \mathrm{C}\left(\mathrm{mg} \mathrm{L}^{-1}\right)$;

$\mathrm{t}$ - Time of sample incubation under temperature of $20^{\circ} \mathrm{C}$, and

$\mathrm{t}_{1}$ - Time of sample incubation under any temperature $\mathrm{T}$.

Equation 4 was obtained using the relation between STREETER \& PHELPS [eq.(2)] and the progression equation of biochemical oxygen demand over time (Equation 1), which is a kinetics model of first order reaction. The equation has the simplification that the last biochemical oxygen demand $\left(\mathrm{BOD}_{\mathrm{u}}\right)$ does not vary with temperature, which by the very definition of the variable is acceptable, and the increasing temperature only favors its range to occur in a shorter period of time.

For obtaining $\theta$ from Equation 4, it was necessary to know in addition to the average values $\mathrm{BOD}_{2.5}^{35}, \mathrm{BOD}_{3.16}^{30}$ and $\mathrm{BOD}_{5}^{20}$ of the ESF, ARL and ARS samples, the deoxygenation coefficient at $20{ }^{\circ} \mathrm{C}\left(\mathrm{k}_{20}\right)$ of each of these samples, given that this temperature is used as a reference in this type of analysis. Samples from the same sites were incubated for a period of 22 days, with 2 repetitions and performing an identical analysis, already presented, for obtaining the values of BOD. The aliquots used in wastewater on the fifth day were similar to the previous test; however, it was smaller in later days, since oxygen consumption increases over time. The application Sigmaplot 10.0 was used to fit equations and thereby obtain the coefficients $\mathrm{k}_{20}$ through the method of non-linear regression, which according to OKE \& AKINDAHUNSI (2005) is the most accurate with larger determination coefficients and smaller estimation errors.

To examine whether the estimated temperature coefficient $\left(\theta_{\mathrm{EST}}\right)$ was influenced by the type of wastewater, we used the Tukey test $(\alpha=0.05)$. The "t" test $(\alpha=0.05)$ was used to compare the values of $\theta$ obtained in this experiment and those obtained when this parameter was calculated using the value of $\theta$ recommended for studies of water quality and wastewater treatment, which is 
1.047. The same test was used to compare the results obtained after calculating the $\theta_{\mathrm{EST}}$ using Equation 4, the deoxygenation coefficient obtained in the laboratory, and the typical values reported in the literature. Also, we compared the estimated $\theta$ coefficients, verifying if there was effect of incubation temperature of ESF, ARL and ARS samples ("t" test with $\alpha=0.05$ ).

\section{RESULTS AND DISCUSSION}

The mean values of BOD in wastewater samples after removal of the discrepant data are shown in Table 1.

TABLE 1. Average biochemical oxygen demand in wastewater samples submitted to different time-temperature binomials.

\begin{tabular}{cccc}
\hline \multirow{2}{*}{ Time-temperature binomial } & \multicolumn{3}{c}{ BOD $\left(\mathrm{mg} \mathrm{L}^{-1}\right)$} \\
\cline { 2 - 4 } & ESF & ARL & ARS \\
\hline $2.5 \mathrm{~d} / 35^{\circ} \mathrm{C}$ & $174 \pm 11$ & $11,819 \pm 1,821$ & $1,729 \pm 458$ \\
$3.16 \mathrm{~d} / 30{ }^{\circ} \mathrm{C}$ & $164 \pm 18$ & $13,802 \pm 1,408$ & $2,067 \pm 322$ \\
$5 \mathrm{~d} / 20^{\circ} \mathrm{C}$ & $172 \pm 10$ & $12,080 \pm 1,811$ & $2,400 \pm 261$ \\
\hline
\end{tabular}

ESF - sanitary sewage treated in septic tank; ARL - dairy wastewater; ARS - swine wastewater.

Comparing the values obtained for the time-temperature binomial $2.5 \mathrm{~d} / 35^{\circ} \mathrm{C}$ and $3.16 \mathrm{~d} / 30{ }^{\circ} \mathrm{C}$ of each wastewater with the obtained in the "standard" $5 \mathrm{~d} / 20{ }^{\circ} \mathrm{C}$ of the same, it appears that BOD values are close (statistically equal, comparing two by two, by "t " test with $\alpha=$ 0.05), supporting the hypothesis that is possible to estimate $\mathrm{BOD}_{5}^{20}$ from the data of $\mathrm{BOD}_{3.16}^{30}$ and $\operatorname{BOD}_{2.5}^{35}$.

The chemical oxygen demand in samples of sewage treated in septic tanks (ESF), dairy wastewater (ARL) and swine wastewater (ARS) was, respectively, 564, 24,653 and 4,300 $\mathrm{mg} \mathrm{L}^{-1}$. With relation $\mathrm{BOD}_{5}^{20} / \mathrm{COD}$ of $0.30,0.49$ and 0.56 respectively for ESF, ARL and ARS samples. It is observed that the ESF presented the lowest rate of biodegradability, which is justified by the fact that it has been subjected to a type of pre-treatment. The remaining samples of wastewater are raw effluents, and we note that it have the potential to be biologically treated. The same samples of effluent were used to obtain the first order $\mathrm{k}_{20}$, being the samples incubated at $20{ }^{\circ} \mathrm{C}$, obtaining in this first adjustment the valuesof $0.11,0.13$ and $0.07 \mathrm{~d}^{-1}$ respectively for ESF, ARL and ARS samples. The obtained values differ from the values normally reported for ESF $(0.12 \sim 0.23$, according to METCALF \& EDDY, 2003) and the ones related to agro industrial effluents (0.24 to ARL, according to SARAIVA et al., 2007 and 0.24 to ARS according to FIA et al., 2004, cited by FIA et al., 2007). Among the various explanatory hypotheses for this difference, we concluded that the most plausible would be the existence of nitrogen demand (consumption of oxygen to convert reduced forms of nitrogen to nitric forms) interfering with the results of biochemical oxygen demand which, by definition, only measures the concentration (indirectly) of the carbonaceous fraction (SIWIEC et al., 2011).

GREEN \& WARD (2011) reported that nitrogen demand in raw wastewater or after primary treatments begins after the fifth or eighth day of incubation of the sample. For this reason, in this study, we eliminated the data obtained after these days, in a new setting. Thus, the new values of deoxygenation coefficient were $0.28,0.32$ and $0.41 \mathrm{~d}^{-1}$, respectively for ESF, ARL and ARS. For the two first effluents, we used data of the BOD progression to the eighth day, which provided adjustment of the model equation of first order (Equation 1) at high determination coefficient. Regarding the ARS, we used the progression data until the fifth day, due to the high concentration of nitrogen and nitrogen rapid beginning phase. For comparative purposes, BRANDÃO et al. (2000) found a concentration of $936 \mathrm{mg} \mathrm{L}^{-1}$ of nitrogen in ARS, being this concentration dependent on the type of animal feed (ORRICO JR. et al., 2010), while the typical concentration in sanitary sewage is about $45 \mathrm{mg} \mathrm{L}^{-1}$. The confirmation of settlement in late purge data of BOD progression 
was evident because higher correlation coefficients and smaller errors of estimation for the fitted equations were obtained.

Given the difference between the values of coefficients $\mathrm{k}_{20}$ of the first (without removing the late data) and second adjustment (with purge after the fifth or eighth day) and the typical values of literature, we found that the estimation adopted to obtain the deoxygenation coefficient $\left(\mathrm{k}_{20}\right)$ influenced the value of the temperature coefficient $(\theta)$. For the calculation of $\theta$, the eq.(4) was used applying the $\mathrm{k}_{20}$ values obtained in laboratory (Tables 2 and 3) and typical of literature (Table 4), in addition to the relation between biochemical demands after incubation at 2.5 and 3.16 days under $30^{\circ} \mathrm{C}$ and $35^{\circ} \mathrm{C}$ respectively, with $\mathrm{BOD}_{5}^{20}$.

TABLE 2. Estimated temperature coefficients $\left(\theta_{\mathrm{EST}}\right)$ for the different wastewater according to the time-temperature binomial used in samples incubation and the $\mathrm{k}_{20}$ value obtained in laboratory (without discard late values).

\begin{tabular}{clll}
\hline \multirow{2}{*}{ Time-temperature Binomial } & \multicolumn{3}{c}{ Wastewater } \\
\cline { 2 - 4 } & \multicolumn{1}{c}{ ESF } & \multicolumn{1}{c}{ ARL } & ARS \\
\hline $35{ }^{\circ} \mathrm{C} / 2.5 \mathrm{~d}$ & $1.048 \pm 0.008 \mathrm{a}$ & $1.046 \pm 0.019 \mathrm{a}$ & $1.020 \pm 0.020 \mathrm{~b}$ \\
$30{ }^{\circ} \mathrm{C} / 3.16 \mathrm{~d}$ & $1.041 \pm 0.015 \mathrm{~b}$ & $1.070 \pm 0.028 \mathrm{a}$ & $1.028 \pm 0.021 \mathrm{~b}$ \\
Average & $1.044 \pm 0.013$ & $1.060 \pm 0.027$ & $1.025 \pm 0.021$ \\
\hline
\end{tabular}

Averages followed by the same letter in each line do not differ significantly by the Tukey test $(\alpha=0.05)$.

ESF - sanitary sewage treated in septic tank; ARL - dairy wastewater; ARS - swine wastewater.

TABLE 3. Estimated temperature coefficients $\left(\theta_{\mathrm{EST}}\right)$ for the different wastewater according to the time-temperature binomial used in samples incubation and the $k_{20}$ value obtained in laboratory (discarding late values).

\begin{tabular}{llll}
\hline \multirow{2}{*}{ Time-temperature Binomial } & \multicolumn{3}{c}{ Wastewater } \\
\cline { 2 - 4 } & ESF & ARL & ARS \\
\hline $35{ }^{\circ} \mathrm{C} / 2.5 \mathrm{~d}$ & $1.050 \pm 0.013 \mathrm{a}$ & $1.040 \pm 0.022 \mathrm{a}$ & $0.999 \pm 0.031 \mathrm{~b}$ \\
$30{ }^{\circ} \mathrm{C} / 3.16 \mathrm{~d}$ & $1.039 \pm 0.027 \mathrm{a}$ & $1.071 \pm 0.034 \mathrm{a}$ & $1.011 \pm 0.042 \mathrm{~b}$ \\
Average & $1.044 \pm 0.022$ & $1.057 \pm 0.033$ & $1.006 \pm 0.038$ \\
\hline
\end{tabular}

Averages followed by the same letter in each line do not differ significantly by the Tukey test $(\alpha=0.05)$.

ESF - sanitary sewage treated in septic tank; ARL - dairy wastewater; ARS - swine wastewater.

For the obtainment of the coefficient values of Table 4, we used the values of deoxygenation coefficients of $0.17 ; 0.24$ and $0.24 \mathrm{~d}^{-1}$, respectively for ESF, ARL and ARS.

TABLE 4. Estimated temperature coefficients $\left(\theta_{\mathrm{EST}}\right)$ for the different wastewater according to the time-temperature binomial used in samples incubation, typical $k_{20}$ values present in literature.

\begin{tabular}{llll}
\hline \multirow{2}{*}{ Time-temperature Binomial } & \multicolumn{3}{c}{ Wastewater } \\
\cline { 2 - 4 } & \multicolumn{1}{c}{ ESF } & \multicolumn{1}{c}{ ARL } & ARS \\
\hline $35{ }^{\circ} \mathrm{C} / 2.5 \mathrm{~d}$ & $1.049 \pm 0.009 \mathrm{a}$ & $1.049 \pm 0.031 \mathrm{a}$ & $1.010 \pm 0.025 \mathrm{~b}$ \\
$30{ }^{\circ} \mathrm{C} / 3.16 \mathrm{~d}$ & $1.040 \pm 0.018 \mathrm{~b}$ & $1.071 \pm 0.034 \mathrm{a}$ & $1.022 \pm 0.031 \mathrm{c}$ \\
Average & $1.044 \pm 0.015$ & $1.061 \pm 0.034$ & $1.017 \pm 0.029$ \\
\hline
\end{tabular}

Obs.: The used $\mathrm{k}_{20}$ values were of $0.17,0.24$ and $0.24 \mathrm{~d}^{-1}$, respectively for the samples of sanitary sewage treated in septic tank (ESF), dairy wastewater (ARL) and swine wastewater (ARS). Averages followed by the same letter in each line do not differ significantly by the Tukey test $(\alpha=0.05)$.

Using the "t" test $(\alpha=0.05)$ for comparing the coefficients of each wastewater in two different temperatures (comparison between $\theta_{30}$ and $\theta_{35}$ of each wastewater), we found that the $\theta_{\text {EST }}$ did not significantly vary when obtained from data generated in samples incubated at temperatures of 30 or $35^{\circ} \mathrm{C}$, with exception of what was obtained for the sample of ESF, using the $\mathrm{k}_{20}$ of the first 
adjustment. In other settings and wastewater, there was no significant difference, indicating that the two temperatures are in the same range that generates similar results, corroborating GOTAAS (1948) and ZANONI (1967). Both authors found that there are more pronounced increase of k, given the higher value of $\theta$ in the range up to $15{ }^{\circ} \mathrm{C}$, lower by $30 \sim 35{ }^{\circ} \mathrm{C}$ and decrease above the optimum range $\left(30 \sim 35{ }^{\circ} \mathrm{C}\right)$, a condition in which occurs denaturation of proteins and death of microorganisms.

Considering then the condition in which $\theta$ does not vary within the studied range and using the average values of $\theta$, shown in Table 3 , Figure 1 was constructed to simulate the effect of temperature on the coefficient $\mathrm{k}$ (from the $\mathrm{k}_{20}$ found for the samples, after purging the late data in the second adjustment).

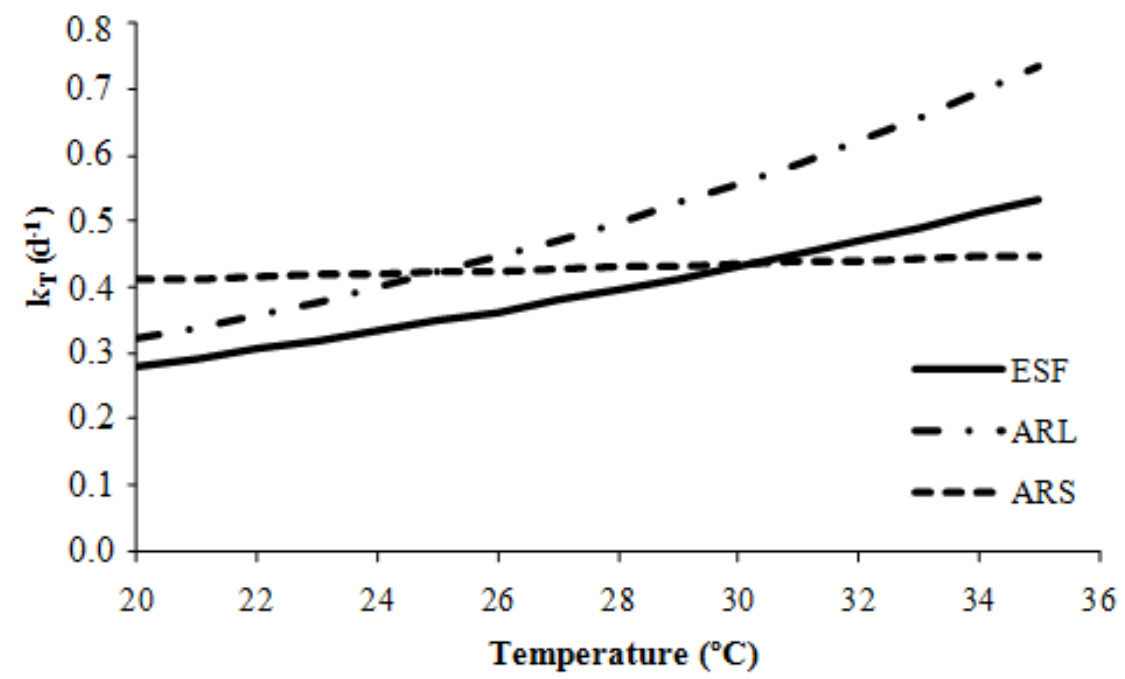

FIGURE 1. Relation between $\mathrm{k}$ and the temperature in the wastewater used (discarding late data).

Regarding the results of the comparative analysis between the temperature coefficients of wastewater presented in Tables 2, 3 and 4 (Tukey test with $\alpha=0.05$ ), we observed that in five comparisons, the values of $\theta$ were to ARS statistically lower than $\theta$ for ESF. We noted also that in four of these analyses, the coefficients $\theta$ for ARL and ESF were similar.

SCHROEPFER et al. (1964), CARPENTER et al. (1968) and OLIVEIRA et al. (2005) found values, respectively, of 1.056, 1.016 and 1.019 for samples of polluted rivers, wastewater from cellulose and paper industry and raw sanitary sewage. Thus, based on what we obtained, we found that although $\theta$ does not vary over the temperature range of $30-35^{\circ} \mathrm{C}$, the temperature coefficient may vary with the type of wastewater due to factors related to the characteristics of the organic material under review, pictured by variables such as initial concentration, ratio BOD/COD and deoxygenation rate.

Otherwise, when the "t" test ( $\alpha=0.05$ ) is applied, comparing the values of $\theta$ obtained for sewage and dairy wastewater with value 1.047, no significant difference was observed in most comparisons. As exceptions, we mention the values of 1.070 (first adjustment) and 1.071 (third adjustment), both with incubation at $30{ }^{\circ} \mathrm{C}$. Thus, it appears that the value of 1.047 does not imply significant errors in the estimation of $\mathrm{k}$, especially in sewage with low concentration, condition in which this value was originally obtained, and that the concentration of organic matter in the wastewater is not a major factor in the value of the temperature coefficient, since the ARL has higher BOD and the $\theta$ associated to it also did not differ statistically from 1.047.

The obtained results indicated that the coefficient of STREETER \& PHELPS can be used to estimate the rate of degradation of organic materials under different temperatures and also the time required to obtain the $\mathrm{BOD}_{5}^{20}$ in a condition of incubation distinct of the pattern, which is at $20{ }^{\circ} \mathrm{C}$. Thus, the possibility of reducing the time required to obtain the result of $\mathrm{BOD}_{5}^{20}$ is open, being of 
great importance from both for the operational point of view of wastewater treatment stations and for the control of water quality.

\section{CONCLUSIONS}

We found that for analysis of BOD wastewater, it is possible to reduce the time of incubation of the samples with an increase in temperature;

The temperature coefficient $(\theta)$ varied with the type of wastewater analyzed, but did not change with temperature in the evaluated range $\left(30-35{ }^{\circ} \mathrm{C}\right)$, indicating the possibility to estimate with good precision, the coefficient $\mathrm{k}$ using values $\theta$ obtained in this range;

The use of the coefficient of 1.047 did not implied significant errors in the estimation of $k$, especially for wastewater with low concentrations of organic matter. These results demonstrate that the coefficient obtained by STREETER \& PHELPS (1925) can be used to estimate the time required for incubation of samples at different temperatures.

\section{ACKNOWLEDGEMENTS}

To the National Council for Scientific and Technological Development (CNPq), for supporting this study.

\section{REFERENCES}

APHA - American Public Health Association; AWWA - American Water Works Association; WEF - Water Environment Federation. Standard methods for the examination of water and wastewater. 22.ed. Washington, 2012. 1496 p.

BRANDÃO, V. S.; MATOS, A. T.; MARTINEZ, M. A.; FONTES, M. P. P. Tratamento de águas residuárias da suinocultura utilizando-se filtros orgânicos. Revista Brasileira de Engenharia Agrícola e Ambiental, Campina Grande, v.4, n.3, p.327-333, 2000.

CARPENTER, W. L.; VAMVAKIAS, J. G.; GELLMAN, I. Temperature Relationships in Aerobic Treatment and Disposal of Pulp and Paper Wastes. Water Pollution Control Federation Journal, v.40, n.5, p.733-740, 1968.

FIA, R.; MATOS, A. T.; LUIZ, F. A. R.; PEREIRA, P. A. Coeficientes de degradação da matéria orgânica de água residuária da lavagem e descascamento dos frutos do cafeeiro em condições anóxica e aeróbia. Engenharia na Agricultura, Viçosa, v.15, n.1, p.45-54, jan./mar., 2007.

GOTAAS, H. B. Effect of temperature on biochemical oxidation of sewage. Sewage Works Journal, Easton, v.20, n.3, p.441-477, 1948.

GREEN, B.; WARD, G. H. Ultimate biochemical oxygen demand in semi-intensively managed shrimp pond waters. Aquaculture, Amsterdam, n.319, p.253-261, 2011.

HOWINGTON, J. P.; MCFETERS, G. A.; JONES, W. L.; SMITH, J.J. The effect of low temperature on bod in Antarctic Seawater. Water Research, New York, v.28, n.12, p.2585-2587, 1994.

JI, Y.; WANG, Y.; SUN, J.; YAN, T.; LI, J.; ZHAO, T., YIN, X.; SUN, C. Enhancement of biological treatment of wastewater by magnetic field. Bioresource Technology, Essex, v. 101, p.8535-8540, 2010.

MATOS, A. T. Qualidade do meio físico - práticas de laboratório. Viçosa - MG: Imprensa Universitária, UFV, 2012a. 150 p.

MATOS, M. P. Efeito do binômio tempo-temperatura de incubação da amostra na demanda bioquímica de oxigênio de diferentes águas residuárias. 2012. 87 f. Dissertação (Mestrado em Engenharia Agrícola) - Universidade Federal de Viçosa, Viçosa - MG, 2012b. 
MAY, T. G. The effect of temperature on the ultimate BOD of sewage. Thesis (Master Civil Engineering) - Evaston (Ill) - Northwestern University, Evanston, 1971. 66 p.

MENEZES, J. M.; PRADO, R. B.; SILVA JÚNIOR, G. C. S.; MANSUR, K. L.; OLIVEIRA, E. S. Qualidade da água e sua relação espacial com as fontes de contaminação antrópicas e naturais: bacia hidrográfica do rio São Domingos-RJ. Engenharia Agrícola, Jaboticabal, v.29, n.4, p.687698, out./dez., 2009.

METCALF \& EDDY. Wastewater engineering: treatment disposal and reuse. $4^{\text {th }}$ ed. New York: McGraw-Hill, 2003. 1818 p.

ORRICO JÚNIOR, M. A. P.; OCORRICO, A. C. A.; LUCAS JÚNIOR, J. L. Avaliação de parâmetros da biodigestão anaeróbia de dejetos de suínos alimentados com dietas à base de milho e sorgo. Engenharia Agrícola, Jaboticabal, v.30, n.4, p.600-607, jul./ago. 2010.

OKE, I. A.; AKINDAHUNSI, A. A. A statistical evaluation of methods of determining BOD rate. Journal of Applied Sciences Research, Melbourne, v.1, n.2, p.223-227, 2005.

OLIVEIRA, E. C. A.; ARAÚJO, G. M.; ARAÚJO, A. L. C.; BEDA, J. N.; INGUNZA, M. P. D. Caracterização e verificação das variações das taxas de degradação de matéria orgânica em diferentes temperaturas de incubação na ETE Ponta Negra/RN. In: CONGRESSO BRASILEIRO DE ENGENHARIA SANITÁRIA E AMBIENTAL, 23., 2005, Campo Grande. Anais... CD-ROM.

SARAIVA, C. B.; MOREIRA, D. A.; CHAGAS, R. C.; SILVA, D. J.; MATOS, A. T.; FARAGE, J. A. P. Determinação do coeficiente de desoxigenação $\left(\mathrm{k}_{1}\right)$ das águas residuárias de laticínios. Revista do Instituto de Laticínios Cândido Tostes, Juiz de Fora, v.62, n.367, p.254-257, 2007.

SCHROEPFER, G. J.; ROSINS M. L.; SUSAG, R. H. The research program on the Mississipi River in the vicinity of Minneapolis and St. Paul. Air and Water Polluttion International Journal, Dordrecht, v.7, p.373-391, 1964.

SIMON, F. X.; PENRU, Y.; GUASTALLI, A. R.; LLORENS, J.; BAIG, S. Improvement of the analysis of the biochemical oxygen demand (BOD) of Mediterranean seawater by seeding control. Talanta, London, n.85, p.527-532, 2011.

SIWIEC, T.; KIEDRYNSKA, L.; ABRAMOWICZ, K.; REWICKA, A.; NOWAK, P. BOD measuring and modeling amethods-review. Annals. Warsaw University of Life Sciences - SGGW, Poland, Land Reclam, v.2, n.43. p.143-153, 2011.

STREETER, H. W.; PHELPS, E. B. A study of the natural purification of the Ohio River. Public Health Bulletin 146: U.S. Public Health Service, Washington DC, 1925.

THERIAULT, E. J. The Oxygen demand of polluted waters. Public Health Bulletin, Washington, n.173, p.174-175, 1927.

UDEIGWE, T. K.; WANG, J. J. Biochemical oxygen demand relationships in typical agricultural effluents. Water Air Soil Pollut, Dordrecht, v.213, p.237-249, 2010.

ZANONI, A. E. Use for frozen waste water as a test substrate. Public Works, New York, n.96, p.7274, 1965.

ZANONI, A. E. Waste water deoxygenation at different temperatures. Water Research, New York, v.1, p.543-566, 1967. 